\title{
Sedimentation of load in a step-pool rock ramp fishway with biotechnical embedded elements
}

\author{
Tomasz Tymiński, Justyna Mumot, Dorota Karpowicz \\ Wroctaw University of Environmental and Life Sciences, Institute of Environmental Engineering, Plac Grunwaldzki 24, \\ 50-363 Wrocław, Poland, e-mail: tomasz.tyminski@up.wroc.pl
}

Xia Jianxin

Minzu University of China, Institute of Environment \& Resources Protection for Minority Areas, 27 Zhong-Guan-Cun, Beijing 100081, PR China, e-mail: jxxia@vip.sina.com

\begin{abstract}
One of the fundamental actions undertaken to preserve the ecological continuity of rivers is to design and construct fishways. The considerable demand for and insistence on the construction of such structures has resulted in a more and more conventional approach to their design. However, every single hydraulic engineering structure with a negative impact on the possibility of a watercourse in fact requires an individual approach. Often, the solutions which are the most convenient and the easiest for a designer are not in the least the best ones for migratory fish. Semi-natural fishways in particular pose a technical challenge that requires an interdisciplinary approach. Designing and constructing them correctly is not an easy task, but once it is achieved, the structure is highly effective in terms of fish migration and the formation of new habitats. Another, equally important issue related to fishways of this type is their long-term usage and proper maintenance. In this case, it is crucial to consider the transport of load through the fishway channel, and more particularly its sedimentation in zones of lower flow velocities. This paper presents a qualitative analysis of the sedimentation of load based on laboratory research carried out on a model of a vegetated fishway. This research was performed to investigate and confirm the expected locations of accumulation of load in a semi-natural vegetated step-pool rock ramp fishway. Experiments show that the sedimentation of load in fish passes may be a highly problematic issue and may require that more attention be given to the proper upkeep of fishways. It may be necessary to address the problem of fishway maintenance and deal with fishways as structures that change over time not only because of hydrological conditions, but also due to the yearly growth cycle of vegetation.
\end{abstract}

Keywords: fishway, biotechnical embedded elements, suspended load, transport of sediment

Submitted 3 January 2017, revised 13 February 2017, accepted 5 May 2017

\section{Introduction}

In line with the policy of sustainable development, which is in effect in all EU member states, the concept of ecological river continuity (Vannote et al. 1980) is closely related to fishways (the Water Framework Directive 2000/60/EC (WFD) of 23 October 2000, the Water Law Act). Because of the high number of water engineering structures, such as dams and weirs, that divide rivers into sections, it is necessary to construct devices that can connect tailwaters and headwaters and enable the passage between them. Fishways are intended to allow the migration of aquatic organisms, which is a prerequisite for the biodiversity of rivers and their relatively natural ecosystems. Fishways can be built in various designs (Weise, Thürmer 1999; Zhou et al. 2011; Szcześniak, Tymiński 2012; WWF 2016) and may take the form of either heavy concrete constructions, novel technical solutions such as fish lifts or even vegetated bypasses resembling a natural watercourse (Figs. 1, 3). This last type has one distinctive advantage, namely the way in which this kind of fish pass operates and is incorporated into its natural environment. Semi-natural fishways are ideally integrated into the landscape and form new habitats for the fauna and flora closely related to the river ecosystem. Unfortunately, structures which include embedded biological elements pose several problems even at the design stage (Teppel et al. 2013). Careful attention should also be given to the difficulties a

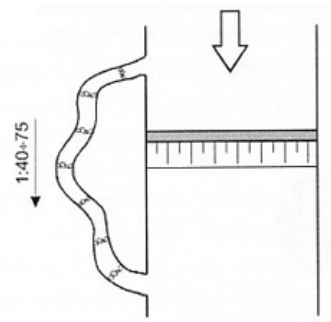

b

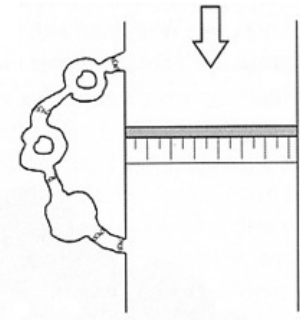

Fig. 1. Types of bypass fishways according to FAO\&DVWK (2002) and WWF (2016) 
related to the proper running and upkeep of these structures (Mokwa, Wiśniewolski 2008; WWF 2016).

\section{Characterisation of load}

The transport of load in rivers is a vast and relatively well studied subject (Parzonka 1991; Mokwa 2002; Głowski et al. 2004; Mokwa et al. 2004; Popek 2006; Bednarczyk, Duszyński 2008; Kałuża, Hämmerling 2015; Radecki-Pawlik et al. 2017). Clearly, what flows in a river bed is not just pure water. Rivers transport vast amounts of load that have various properties. Here, the river load should be understood as the material resulting from all types of erosion, which partly or even entirely ends up in streams and rivers, as well as the material present in the river bed (Mokwa, Banasiak 1999; Mokwa 2002; Mokwa et al. 2004). The main criterion for the classification of load is the regime of its transport, which is closely related to the size of particles and the velocity of flowing water (Bednarczyk, Duszyński 2008). In river hydraulics, three types of river load can be distinguished: bed load, suspended sediment load and dissolved material (Chow 1959; Graf 1984; Radecki-Pawlik, Skalski 2008; RadeckiPawlik 2013; Rowiński, Radecki-Pawlik 2015; Plesiński et al. 2015). A slightly different classification is proposed by Parzonka (1991), who divides the river load into: bed load, carried load and suspended load. Mokwa (2002) specifies that the term "carried load" refers to all of the solid material that is contained in a stream of water above the bed. The different types of load are subjected to different transport mechanisms. For most rivers in the Lower Silesia region (apart from their upper reaches) one can assume that the proportion of carried load and suspended load prevail. The conclusions of the Mokwa research team for the Odra (Banasiak 1999; Mokwa, Banasiak 1999) and the Bóbr (Głowski et al. 2004; Mokwa et al. 2004) drawn from long-term measurements of the suspended load, carried load and bed load are of particular value: according to the team, the bed load constitutes only $20 \%$ of the overall transport of river material. The carried load amounts to $15 \%$, but together with the suspended load it accounts for $80 \%$ of the overall transport of material. Notably, the characteristic diameter of load particles for the lowland Odra river is $d_{50}=0,4-3 \mathrm{~mm}$ (Mokwa, Banasiak 1999; Mokwa 2002). This fact has been taken into account in the presented laboratory research on the motion of load in a semi-natural fishway. In this case, it is crucial to consider the transport of suspended load through a semi-natural fishway with vegetated build-up, and more particularly with its sedimentation in vegetated zones of lower flow velocities. Nowadays, little is known about this problem. There is still little field or laboratory data available. Some of the only important contributions are the investigations by Tsujimoto (1999), Elliott (2000), Mokwa (2002) and Stephan, Schmid (2006). Therefore, the main goal of our study is to perform a qualitative analysis of the sedimentation of load based on laboratory research carried out on a model of a vegetated fishway. This research was performed to investigate and confirm the expected locations of accumulation of suspended load in a semi-natural vegetated step-pool rock ramp fishway. The transport of bed load has not been investigated.

\section{Motion of sediment in a semi-natural fishway}

In an open channel with biotechnical build-up, the hydraulic impact of vegetation on flow conditions, especially on flow velocity, is evident (Tsujimoto 1999; Elliott 2000; Stephan, Schmid 2006; Tymiński 2012; Tymiński, Kałuża 2013). There is a relationship between flow velocity and the motion of sediment in a river bed (Hjulström 1935; Chow 1959; Graf 1984; Parzonka 1991; Elliott 2000; Stephan, Schmid 2006; Radecki-Pawlik, Skalski 2008; Radecki-Pawlik 2013, Rowiński, Radecki-Pawlik 2015; Plesiński et al. 2015; Radecki-Pawlik et al. 2017). So, in various hydraulic conditions, solid particles may be alternatively subjected to erosion, transport or sedimentation. The same phenomena that occur in the main river bed will also occur in a semi-natural fishway. Because of the specific hydraulic conditions necessary for the correct operation of fishways, the area in which they are constructed allows any of these three processes. We may expect that the bed of a fishway will erode in the area reached by the attraction current and that the conditions in the resting zones for fish will favour the sedimentation of load. Consequently, it is necessary to conduct research aimed at locating the zones in which each of the load transport regimes occur.

In the analysis of processes related to the transport of load, Hjulström's diagram may be helpful (Fig. 2). This graph was designed in 1935 at Uppsala University by Swedish scientist Filip Hjulström (Hjulström 1935). It allows one to determine the flow velocity for which each particle of a given diameter will undergo a given process: erosion, transport or sedimentation (Hjulström 1935; Gordon et al. 2004).

Because of the unique way in which fishways operate, particular attention should be given to the process of sedimentation of load. In many cases the design of a fishway may prevent coarse load from entering into it (with the use of special sills, covers, filtering grilles, etc.); therefore, in such a structure the load will consist mainly of fine particles. Even an initial analysis of Hjulström's diagram 


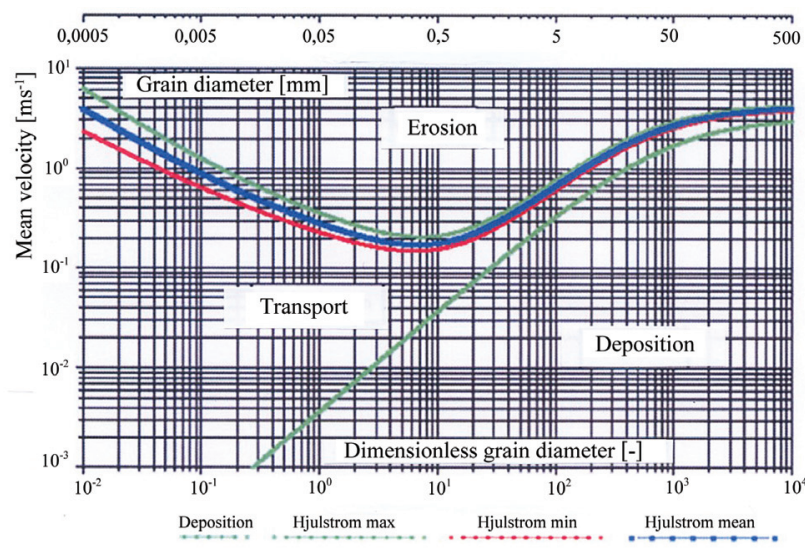

Fig. 2. Hjulström's diagram (Hjulström 1935)

allows one to determine which velocities favour each of the transport regimes for particles of small diameters. By using the graph one can also easily determine the fractions of load which will sediment for a given flow velocity and inversely for which velocity a given fraction will fall onto the channel bed.

The motion of load in a fishway is significantly linked to the flow velocity of water (Tymiński, Mumot 2015; Mumot, Tymiński 2016). It is not only the value that is significant, but also the spatial distribution of velocity (Teppel, Tymiński 2013; Tymiński, Kałuża 2013; Mumot, Tymiński 2015). Moreover, some limitations apply on account of the ichthyofauna (the varied dimensions, motoric characteristics and swimming abilities of fish); these are shown in detail in Table 1.

\section{Materials and methods \\ 4.1. Laboratory fishway model}

The experimental research was carried out in Wołoszyn Water Laboratory at Wrocław University of Environmental and Life Sciences. The physical model of a fishway (Fig. 3) was built in a trapezoid flume measuring $15 \mathrm{~m}$ in length with a side slope of 1:1 and bottom width $0,9 \mathrm{~m}$. The roughness coefficient for the entire length of the flume bottom was $n=0,012 \mathrm{~m}^{-1 / 3} \cdot \mathrm{s}$ (according to

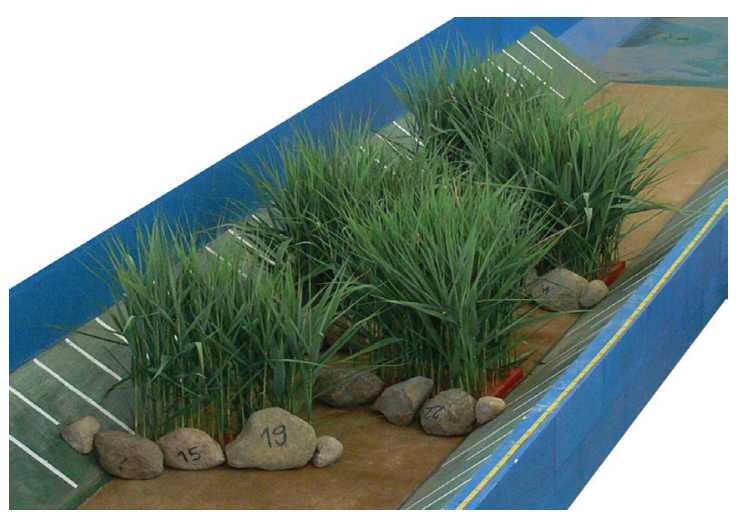

Fig. 3. Laboratory model of a fishway with biotechnical build-up
Table 1. Fishway design guidelines (FAO \& DVWK 2002)

\begin{tabular}{|c|c|}
\hline \multicolumn{2}{|c|}{ Permissible water flow velocities in fishways } \\
\hline Type of fish & Flow velocities \\
\hline Big-size fish like salmonids (salmon, trout) & $v<2,0 \mathrm{~m} \cdot \mathrm{s}^{-1}$ \\
\hline Medium-size fish like cyprinids (chub, barbel) & $v<1,5 \mathrm{~m} \cdot \mathrm{s}^{-1}$ \\
\hline Small fish and juveniles & $v<1,0 \mathrm{~m} \cdot \mathrm{s}^{-1}$ \\
\hline Velocities at the inlet of the upper water & $v<1,2 \mathrm{~m} \cdot \mathrm{s}^{-1}$ \\
\hline Velocities at the fishway mouth & $v<1,9 \mathrm{~m} \cdot \mathrm{s}^{-1}$ \\
\hline \multicolumn{2}{|c|}{ Hydraulic parameters for fishways } \\
\hline Parameter & Size \\
\hline Specific discharge & $q>0,1 \mathrm{~m}^{2} \cdot \mathrm{s}^{-1}$ \\
\hline Bottom slope & $1: 75-1: 20$ \\
\hline Width of fishway & $b>0,8 \mathrm{~m}$ \\
\hline Length of chamber & $L>4,0 \mathrm{~m}$ \\
\hline Difference in water levels between chambers & $\Delta h=0,05-0,15 \mathrm{~m}$ \\
\hline Flow depth & $t=0,2-1,5 \mathrm{~m}$ \\
\hline Mean velocity & $v=0,4-0,6 \mathrm{~m} \cdot \mathrm{s}^{-1}$ \\
\hline Diameter of stones used & $d=0,4-0,7 \mathrm{~m}$ \\
\hline Width of slots & $s=0,1-0,5 \mathrm{~m}$ \\
\hline
\end{tabular}

the Ven Te Chow parameter) (Chow 1959; Wołoszyn et al. 1994; Franzini, Finnemore 2001). The fishway was supplied with water from the laboratory installation with a forced water circulation system (Fig. 4). A circular measuring weir was installed in the flume inlet. The flow rate in the laboratory flume was set to $40 \mathrm{dm}^{3} \cdot \mathrm{s}^{-1}$. The fishway model (at a scale of 1:3 or 1:4) main flume measured $3 \mathrm{~m}$ in length and consisted of repetitive modules which in natural conditions could form a bypass channel of an arbitrary length (Fig. 1).

The biotechnical embedded elements consisted of configurations of triangular concrete flowerpots in which plant stems were placed (Figs. 3, 5). Common reed (Phragmites australis (Cav.) Trin. ex Steudel) was used for the experiments. This species is common throughout the entire world and can withstand a long time in water (Tymiński, Kałuża 2012, 2013). A total of 320 plants were used; their stems were placed into the openings of flowerpots. In order to stabilise the structure, rocks measuring $176,5 \mathrm{~mm}$ $\times 66,1 \mathrm{~mm} \times 97,2 \mathrm{~mm}$ (width $\times$ height $\times$ length, representative dimensions) were used (Fig. 3).

\subsection{Methodology and scope of research}

The qualitative research on the sedimentation of load was carried out for the following range of hydraulic parameters: a) flow rate $Q=30-50 \mathrm{dm}^{3} \cdot \mathrm{s}^{-1} ; \mathrm{b}$ ) average instantaneous velocities $v=0-1 \mathrm{~m} \cdot \mathrm{s}^{-1} ; \mathrm{c}$ ) flow depth $h=0,15-0,23 \mathrm{~m}$. The picture of the velocity field (Fig. 5 ) was obtained from the measurements taken using an electromagnetic PEMS-E30 velocity meter at the nodes of 


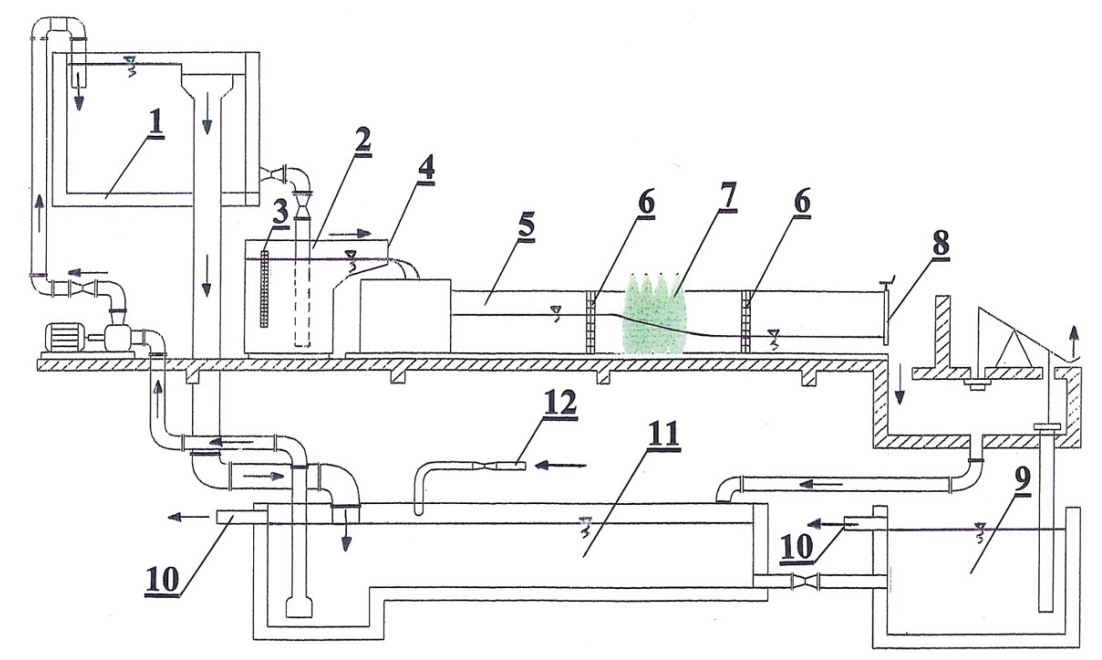

Fig. 4. Schematic view of the measurement set-up (1 - higher tank, 2 - measuring tank, 3 - gauge, 4 - circular measuring weir, 5 - flume, 6 - piezometers, 7 - fishway with biotechnical build-up, 8 - weir, 9 - measuring tank, 10 - to sewers, 11 - main tank, 12 - supply pipeline)

a mesh measuring $0,10 \times 0,15 \mathrm{~m}$, at a total of 360 measurement points. In order to relate the results to the real conditions in a fishway with natural dimensions, one must recalculate the values according to the scale determined based on the hydrodynamic criterion for Froude similarity (Franzini, Finnemore 2001; Tymiński et al. 2016; Mokwa, Tymiński 2017). The velocities obtained in the measurements were recalculated for two selected scales of the model: $1: 3$ and 1:4. The flow velocities thus obtained show that the vegetated fishway model meets the requirements for hydraulic conditions in line with fishway design guidelines (DVWK 1996 Larinier 2000; FAO\&DVWK 2002; DWA 2005 Krüger 2008; Adam, Lehmann 2009; DWA 2009, 2010; WWF 2016). The flow velocity values were recalculated for both scales of the model.

During the research, PVC pellets were used to imitate load. These pellets had a skeleton density of $1,39 \mathrm{~g} \cdot \mathrm{cm}^{-3}$, volumetric density of $0,96 \mathrm{~g} \cdot \mathrm{cm}^{-3}$ and the average grain size of $3,05 \mathrm{~mm}$. The pellets feeder consisted of a $2 \mathrm{~m}$ long pole with plastic containers attached to it, measuring $40 \mathrm{ml}$ in volume. The pole had 20 containers located over a $0,9 \mathrm{~m}$-long pole section. Each container was filled with pellets up to $20 \mathrm{ml}$. A single filling consisted of about $384 \mathrm{~g}$ of pellets. The pellets were dispensed to water every 2 minutes during the 60 -minute-long period of observation. Its discharge was $85 \mathrm{~g} \cdot \mathrm{s}^{-1}$. The feeder was placed $2 \mathrm{~m}$ away from the flume inlet, $0,75 \mathrm{~m}$ from the fishway model (in the direction of the water flow). The filling consisted in slowly moving the pole so as to release the pellets from the container. Investigation and observation was documented with photographs (Fig. 6). After the flume was dried, the deposits of the pellets were carefully collected from the bottom of the fishway sections. The pellets were dried and weighed. Based on the photogrammetric analysis of photographic documentation, the sedimentation zones of load were marked on the velocity distribution of the load sedimentation zone.

Based on the photographic documentation of the experiments carried out and the analysis of the documented observation results, the shapes and locations in which load sedimentation occurred were determined. The shapes of the sediment on the fishway bed were superimposed on the

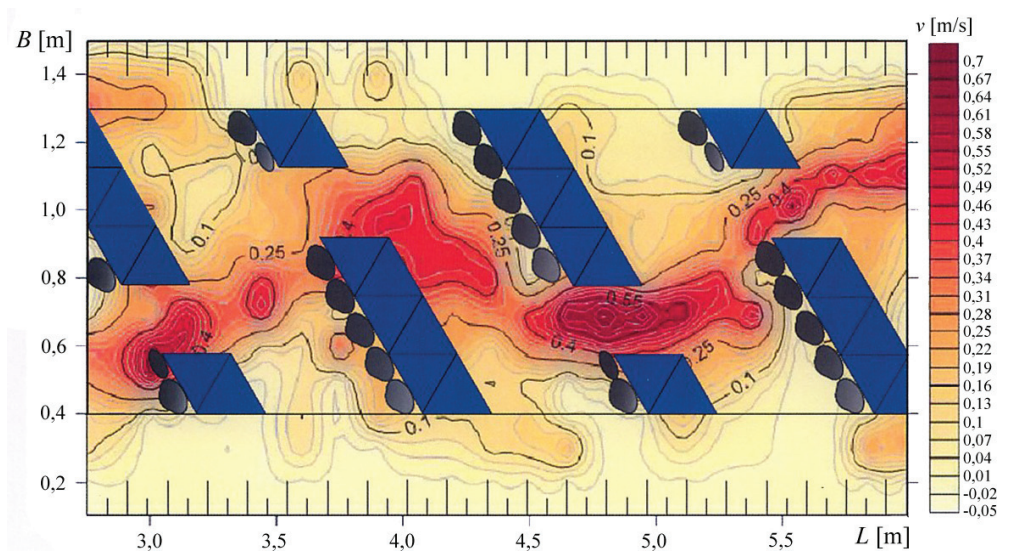

Fig. 5. Distribution of velocity in a fishway with biotechnical build-up 
Table 1. Sample measured results with recalculated real-scale values

\begin{tabular}{|c|c|c|c|c|c|c|c|c|c|c|}
\hline \multirow{3}{*}{ No } & \multicolumn{2}{|c|}{ Coordinates } & \multirow[b]{2}{*}{$\begin{array}{l}\text { Velocity } \\
v_{x}\end{array}$} & \multirow[b]{2}{*}{$\begin{array}{c}\text { Velocity } \\
v_{y}\end{array}$} & \multicolumn{3}{|c|}{ Model scale 1:3 } & \multicolumn{3}{|c|}{ Model scale 1:4 } \\
\hline & $X$ & Y & & & $\begin{array}{c}\text { Scale } \\
\text { coefficient } \\
n_{v}\end{array}$ & $\begin{array}{c}\text { Velocity } \\
v_{x}\end{array}$ & $\begin{array}{c}\text { Velocity } \\
v_{y}\end{array}$ & $\begin{array}{c}\text { Scale } \\
\text { coefficient } \\
n_{v}\end{array}$ & $\begin{array}{c}\text { Velocity } \\
v_{x}\end{array}$ & $\begin{array}{c}\text { Velocity } \\
v_{y}\end{array}$ \\
\hline & {$[\mathrm{m}]$} & {$[\mathrm{M}]$} & {$\left[\mathrm{m} \cdot \mathrm{s}^{-1}\right]$} & {$\left[\mathrm{m} \cdot \mathrm{s}^{-1}\right]$} & - & {$\left[\mathrm{m} \cdot \mathrm{s}^{-1}\right]$} & {$\left[\mathrm{m} \cdot \mathrm{s}^{-1}\right]$} & - & {$\left[\mathrm{m} \cdot \mathrm{s}^{-1}\right]$} & {$\left[\mathrm{m} \cdot \mathrm{s}^{-1}\right]$} \\
\hline 1 & 2,75 & 0,30 & 0,122 & 0,082 & \multirow{2}{*}{1,73} & 0,211 & 0,142 & & 0,244 & 0,164 \\
\hline 2 & 3,45 & 0,50 & 0,007 & 0,046 & & 0,012 & 0,080 & & 0,014 & 0,092 \\
\hline
\end{tabular}

where: $x$ denotes values in the direction of flow and $y$ denotes values in the direction perpendicular to the direction of flow

map of water flow velocities and through this the hydraulic conditions for the formation of load sedimentation zones were determined (Figs. 5-7).

In our experiments, we have observed that the biotechnical embedded elements in the fish pass result in increased filling in the bypass (Fig. 1a), slowing down the stream and reducing the flow velocity at the headwater side. At the entrance to the fish pass, a backwater is formed. This reduction in velocity leads to the sedimentation of part of the load being already carried in the channel before the proper fish pass, i.e., before the first vegetative "bar" (Fig. 8). Mokwa (2002) has also noted this phenomenon in his laboratory research. The subject will be dealt with in another publication, which is currently under preparation. The flow velocities inside the fish pass are highly varied (Fig. 5) and so is the distribution of stream turbulence, as

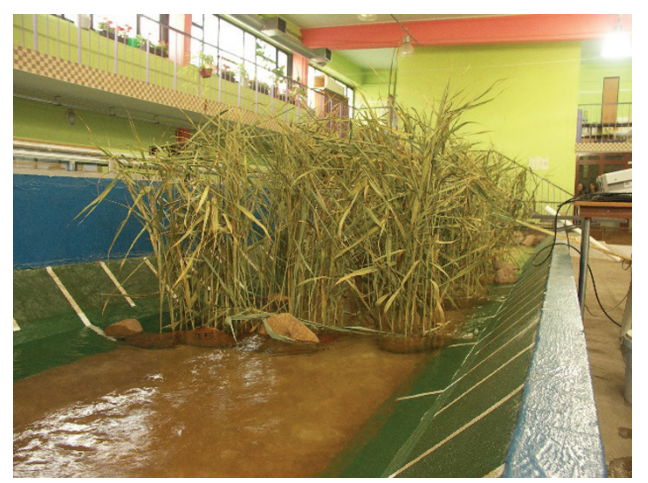

described in detail in a publication by Tymiński and Mumot (2015). There is a distinct sinusoidal current here with a relatively high velocity $v_{M}=0,4-0,7 \mathrm{~m} / \mathrm{s}$ (which would translate to $v_{N}=0,8-1,4 \mathrm{~m} / \mathrm{s}$ in nature). The highest local velocities were observed in the passage areas (narrows) between chambers. In these areas, no sedimentation of load occurs. The load transport capability of the stream is high and enables the transport of load "downstream" to the subsequent chambers and then out of the fish pass. The results of laboratory measurements also show that the flow velocities and the levels of turbulence are the smallest directly behind the plant obstacles ("plant baffles"). These areas are the so-called "calm zones" in the fishway, in which fish can rest on their way. These zones of reduced flow velocity are necessary in practically every fish pass design. Unfortunately, in these "calm zones" of the in-

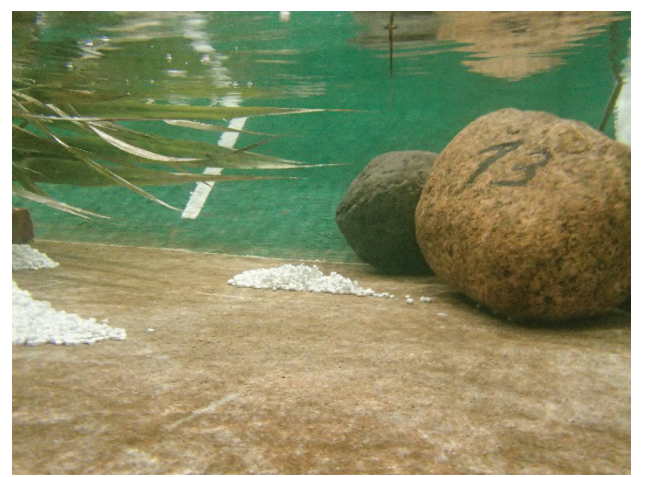

Fig. 6. Experimental research in a water lab: a: (left-hand side) - a model fishway with biotechnical embedded elements; b: (righthand side) - visible sedimentation zones (in white)

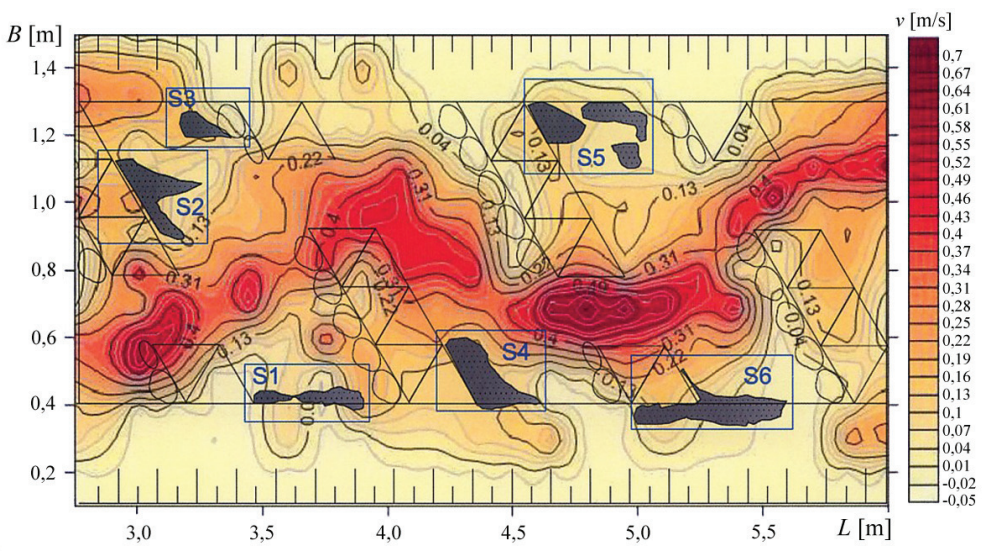

Fig. 7. Zones of load sedimentation (from authors' experiments) 

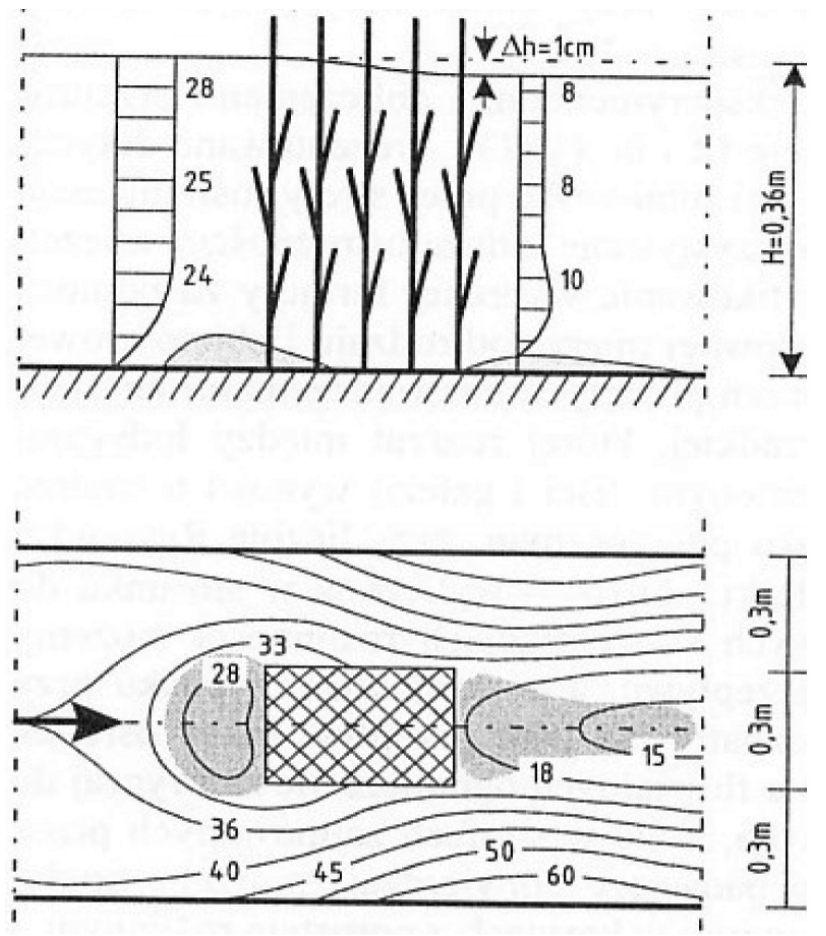

Fig. 8. Results of Mokwa's (2002) experiments: visible sedimentation zones (in dark)

vestigated fish pass intensive sedimentation of load has been observed. The location of the sedimentation zones is shown in Fig. 8.

An analysis of the distribution of the sedimentation zones and of the flow velocity isolines shows that the limiting velocity value that triggers the sedimentation of load grains measuring $3 \mathrm{~mm}$ in diameter is in the range of $v_{\text {on }}=0,13-0,19 \mathrm{~m} \cdot \mathrm{s}^{-1}$.

\section{Results and discussion}

The results of the present research were marked on Hjulström's diagram (Fig. 9). A good correlation with the literature data was obtained. The range of flow velocities $\left(0,001-0,700 \mathrm{~m} \cdot \mathrm{s}^{-1}\right)$ obtained through our own research was related to the curve of the limiting velocity that trig- gers sedimentation, read from Hjulström's diagram for load grain size $d=3 \mathrm{~mm}$. The sedimentation limiting velocity read from the diagram was $v_{o n}=0,20 \mathrm{~m} \cdot \mathrm{s}^{-1}$.

The limiting velocities, for which the sedimentation process begins, obtained based on the method described above, yield a similar range of velocity values. Thus, one may assume that the sedimentation process for the load fraction with $d=3 \mathrm{~mm}$ in a fishway will be triggered for flow velocities not greater than $0,19-0,20 \mathrm{~m} \cdot \mathrm{s}^{-1}$.

\section{Conclusions}

In a properly designed fishway, differences occur in the water flow velocity. For example, there is an attraction current - a rapid, rushing flow which directs fish to the entrance to the fishway and then helps the migrating fish to navigate through it. There are also fish resting zones with calmer hydraulic conditions, e.g. quiet flow, little turbulence and low velocities. This variability of flow parameters in a fishway favours the formation of complex processes of load transport. As shown by our research, the sedimentation of load has a very disadvantageous effect on the fishway. After the laboratory investigation, it can be noted that:

- there is a clear relationship between the hydraulic flow conditions and sediment transport in the fishway;

- the transport and sedimentation of load in a fishway is not steady and changes over time;

- sediment transport and sedimentation significantly depend mainly on the sediment properties and spatial distribution of turbulence and flow velocity;

- in the gaps between the bars, the flow velocity increases due to the cross-section being narrower; bed erosion is to be expected in these places;

- the accumulation of load in a fishway mainly occurs in the resting zones for the fish, i.e., in the areas with reduced flow velocity (directly behind the plant obstacles).

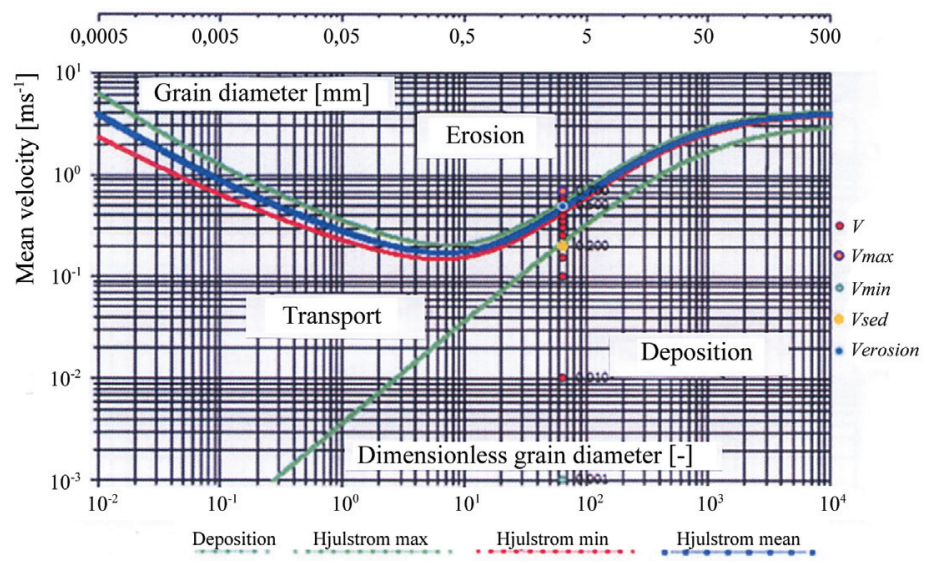

Fig. 9. Hjulström's diagram with the range of velocities for the grain diameter $d_{s r}=3 \mathrm{~mm}$ 
Over time, this process of sedimentation may lead to build-up on the fishway bed, which will decrease its hydraulically active cross-section of flow. This will have further consequences, such as a change in the hydraulic conditions in the structure, clogging of the resting zones for fish and, in extreme cases, the flow of water through the fishway may be brought to a complete halt. This means that structures of this kind require constant monitoring and upkeep, and that their biological and technical nature forces a multi-level approach to their usage. Sometimes, scientific field or laboratory experiments are useful. Also, the investigation results presented here increase knowledge of the hydraulics of streams and the transport and sedimentation of river load in fishways (bypass channels) with a build-up of vegetation. When we consider the difficulties in the representation of natural sediment in laboratory conditions - something that results in the findings of this study having only a qualitative character - it is clear that further experiments in this area should be carried out on real objects.

\section{Bibliography}

Adam B., Lehmann B, 2009, Allgemeine Anforderungen an Fischaufstiegsanlagen, Konferenzmaterialien: Vortrag zur Tagung “Oekologische Durchgängigkeit in Fließgewässern”, (in German), LUA Brandenburg, Lebus, 30 pp.

Banasiak R., 1999, Investigations on suspended load transport in open-channels, (in Polish), PhD thesis, manuscript, Wrocław University of Environmental and Life Sciences, 149 pp.

Bednarczyk S., Duszyński R., 2008, The hydraulic and hydrotechnical basis for river regulation and revitalization, (in Polish), Wydawnictwo Politechniki Gdańskiej, Gdańsk, 224 pp.

Chow V.T., 1959, Open-channel hydraulics, McGraw-Hill Book Company, New York \& London, 680 pp.

DVWK, 1996, Fischaufstieganlagen: Bemessung, gestaltung, funktionskontrolle, (in German), Merkblatt, 232, 113 pp.

DWA, 2005, Fischschutz- und fischabstiegsanlagen: Bemessung, gestaltung, funktionskontrolle, (in German), DWA, 2. Auflage, Hennef, 256 pp.

DWA, 2009, Fischaufstieganlagen und fischpassierbare bauwerke: Gestaltung, bemessung, qualitätssicherung, (in German), DWA-Regelwerk, Merkblatt DWA-M509/2009, Gelbdruck, $302 \mathrm{pp}$.

DWA, 2010, Durchgängigkeit und habitatmodellierung von fließgewässern, (in German), Verlag der Bauhaus-Universität Weimar, 274 pp.

Elliott A.H., 2000, Settling of fine sediment in a channel with emergent vegetation, Journal of Hydraulic Engineering, 126 (8), 570-577, DOI: 10.1061/(ASCE)07339429(2000)126:8(570)
FAO \& DVWK, 2002, Fish passes - design, dimensions and monitoring, Food and Agriculture Organization of the United Nations in arrangement with Deutscher Verband für Wasserwirtschaft und Kulturbaue e.V., Rome, 118 pp.

Franzini J.B., Finnemore E.J., 2001, Fluid mechanics with engineering applications, McGraw-Hill Series in Industrial Engineering and Management, Stanford University, Santa Clara University, McGraw-Hill, Boston, New York, San Francisco, 816 pp.

Głowski R., Kasperek R., Mokwa M., Parzonka W., 2004, Preliminary estimation of bed load transport in lower Bóbr River, (in Polish), Zeszyty Naukowe AR we Wrocławiu, Inżynieria Środowiska XIII, 502, 101-107

Gordon N.D., McMahon T.A., Finlayson B.L., 2004, Stream hydrology: an introduction for ecologists, John Wiley and Sons, $429 \mathrm{pp}$.

Graf W.H., 1984, Hydraulics of sediment transport, McGrawHill Book Company, New York/London, 515 pp.

Hjulström F., 1935, Studies of the morphological activity of rivers as illustrated by the River Fyris, Bulletin of the Geological Institute of the University of Uppsala, 25, 221-527 pp

Kałuża T., Hämmerling M. (eds.), 2015, Design and usage problems of fish passes, (in Polish), Bogucki-WydawnictwoNaukowe, Poznań, 139 pp.

Krüger F., 2008, Anforderungen an fischaufstiegsanlagen, beispiele aus der praxis, [in:] Konferenzmaterialien: Vortrag zum Wasserbaulichen Kolloquium "Oekologische Durchgängigkeit von Fließgewässern”, (in German), Universität Hannover, 15 pp.

Larinier M., 2000, Dams and fish migrations, World Commission on Dams, Environmental Issues, final draft

Mokwa M., 2002, Fluvial process control in anthropogenically modified river beds, (in Polish), Zeszyty Naukowe Akademii Rolniczej we Wrocławiu, 439, seria: Rozprawy CLXXXIX, $137 \mathrm{pp}$.

Mokwa M., Banasiak R., 1999, Measured and calculated suspended load transport intensity on the Odra River in Ścinawa cross-section, (in Polish), [in:] XIX Ogólnopolska Szkoła Hydrauliki "Współczesne Problemy Hydrauliki Wód Śródlądowych“, Instytut Budownictwa Wodnego PAN, Gdańsk-Frombork, 223-228

Mokwa M., Głowski R., Kasperek R., Parzonka W., 2004, Analysis of the silting process in Krzywaniec water reservoir, (in Polish), Zeszyty Naukowe AR we Wrocławiu, Inżynieria Środowiska XIII, 502, 317-324

Mokwa M., Tymiński T., 2017, Hydraulic calculations for fish passes, [in:] Open channel hydraulics, river hydraulics structures and fluvial geomorphology, A. Radecki-Pawlik, S. Pagliara, J. Hradecky, E. Hendrikson (eds.), A Science Publishers Book, CRC Press - Taylor \& Francis Group, London \& New York 
Mokwa M., Wiśniewolski W. (eds.), 2008, Ichthyofauna Protection by hydrotechnical structures, (in Polish), Dolnośląskie Wydawnictwo Edukacyjne, Wrocław, 201 pp.

Mumot J., Tymiński T., 2015, Laboratory research of sedimentation in vertical slot fish passes, (in Polish), [in:] Design and Usage Problems of Fish Passes, T. Kałuża, M. Hämmerling (eds.), Bogucki-Wydawnictwo-Naukowe, Poznań, 109-118

Mumot J., Tymiński T., 2016, Hydraulic research of sediment transport in vertical slot fish passes, Journal of Ecological Engineering, 17 (1), 143-148, DOI: 10.12911/22998993/61203

Parzonka W., 1991, Erosion, transport and sedimentation of load in rivers and reservoirs, (in Polish), [in:] XI Ogólnopolska Szkoła Hydrauliki "Współczesne problemy hydrauliki wód śródlądowych", Instytut Budownictwa Wodnego PAN, Gdańsk, 123-129

Plesiński K., Radecki-Pawlik A.,Wyżga B., 2015, Sediment transport processes related to the operation of a rapid hydraulic structure (boulder ramp) in a mountain stream channel: a polish Carpathian example, [in:] Sediment metters, P. Heininger, J. Cullmann (eds.), Springer International Publishing, Koblenz, 39-58

Popek Z., 2006, Bedload transport conditions in a small lowland river, (in Polish), Rozprawy Naukowe i Monografie, Wydawnictwo SGGW, Warszawa, $230 \mathrm{pp}$.

Radecki-Pawlik A., 2013, On using Artificial Rapid Hydraulic Structures (rhs) within mountain stream channels - some exploitation and hydraulic problems, [in:] Experimental and computational solutions of hydraulic problems, P. Rowiński (ed.), Series: GeoPlanet: Earth and Planetary Sciences, Springer-Verlag, 101-115

Radecki-Pawlik A., Pagliara S., Hradecky J., Hendrikson E. (eds.), 2017, Open channel hydraulics, river hydraulics structures and fluvial geomorphology, CRC Press - Taylor \& Francis Group, London \& New York, 544 pp.

Radecki-Pawlik A., Skalski T., 2008, Bankfull discharge determination using the new Invertebrate Bankfull Assessment Method, Journal of Water and Land Development, 12, 145154, DOI: 10.2478/v10025-009-0011-Z

Rowiński P., Radecki-Pawlik A. (eds.), 2015, Rivers - physical, fluvial and environmental processes, Series: GeoPlanet: Earth and Planetary Sciences, Springer-Verlag, 684 pp.

Stephan U., Schmid B.H., 2006, Process studies on suspended sediment transport in very low re-number flows: laboratory experiments, (in German), WasserWirtschaft, 10, 22-27

Szcześniak E., Tymiński T. (eds.), 2012, Lower Silesia`s environment in the view of natural scientists, (in Polish), University of Wrocław, Wrocław, $186 \mathrm{pp}$.
Teppel A., Tymiński T., 2013, Hydraulic research for successful fish migration improvement - "Nature-Like" fishways, Civil and Environmental Engineering Reports, 10, 125-137 pp.

Teppel A., Tymiński T., Małyszko J., Rudy P., 2013, Construction requirements of "Nature-Like" fishways - model tests, International Forum Topical Issues of Rational Use of Natural Resources, Collection of scientific papers, National Mineral Resources University, St. Petersburg, 188-191

Tsujimoto T., 1999, Fluvial processes in streams vegetation, Journal of Hydraulic Research, 37 (6), 789-803

Tymiński T., 2012, Hydraulic model investigation of flow conditions for floodplains with coniferous and deciduous shrubs, Polish Journal of Environmental Studies, 21 (4), 1047-1052

Tymiński T., Kałuża T., 2012, Investigation of mechanical properties and flow resistance of flexible riverbank vegetation, Polish Journal of Environmental Studies, 21 (1), 201-207

Tymiński T., Kałuża T., 2013, Effect of vegetation on flow conditions in the "Nature-Like" fishways, Rocznik Ochrona Środowiska, 15, 348-360

Tymiński T., Mumot J., 2015, Model tests of hydraulic flow conditions in a fishway with vegetation build-up, (in Polish), Inżynieria Ekologiczna, 44, 227-234

Tymiński T., Mumot J., Strojny R., Karpowicz D., 2016, Analysis of the potential of building ramps in hydrotechnical structures as a means of facilitating fish migration, Acta Scientiarum Polonorum, Formatio Circumiectus, 15 (3), 151-162

Vannote R.L., Minshall G.W., Cummins K.W., Sedell J.R., Cushing C.E., 1980, The river continuum concept, Canadian Journal of Fisheries and Aquatic Sciences, 37 (1), 130-137, DOI: 10.1139/f80-017

Weise A., Thürmer K., 1999, Errichtung einer demonstrationsanlage für verschiedene typen von fischaufstiegsanlagen im hydrolabor schleusingen für die ausbildung von studenten, (in German), Bauhaus-Universität Weimar, Weimar (manuscript), $40 \mathrm{pp}$.

WFD/EC, 2000, Water Framework Directive 2000/60/EC of 23 October 2000, EUR-Lex

Wołoszyn J., Czamara W., Eliasiewicz R., Krężel J., 1994, River and stream regulation, (in Polish), Wydawnictwo Akademii Rolniczej we Wrocławiu, Wrocław, 549 pp.

WWF-Poland, FAO \& DVWK, 2016, Fish passes - design, dimensions and monitoring, (in Polish), polish edition, Warsaw, $128 \mathrm{pp}$.

Zhou Yin-Ting, Yao Bang-Song, Tymiński T., 2011, Fishway as a method of environment protection, [in:] The urban environment of Wrocław city in the view of natural scientists, E. Szcześniak (ed.), University of Wrocław, Zeszyt KN, 5, Wrocław, 10-23 